\title{
Tomato spotted wilt virus Infection Improves Host Suitability for Its Vector Frankliniella occidentalis
}

\author{
P. C. Maris, N. N. Joosten, R. W. Goldbach, and D. Peters
}

Laboratory of Virology, Wageningen University, Binnenhaven 11, 6709 PD Wageningen, the Netherlands. Accepted for publication 16 March 2004.

\begin{abstract}
Maris, P. C., Joosten, N. N., Goldbach, R. W., and Peters, D. 2004. Tomato spotted wilt virus infection improves host suitability for its vector Frankliniella occidentalis. Phytopathology 94:706-711.

The effect of Tomato spotted wilt virus (TSWV) infection on plant attractiveness for the western flower thrips (Frankliniella occidentalis) was studied. Significantly more thrips were recovered on infected than were recovered on noninfected pepper (Capsicum anпиит) plants in different

infected pepper plants, and this effect also was found for TSWV-infected Datura stramonium. Thrips behavior was minimally influenced by TSWV-infection of host plants with only a slight preference for feeding on infected plants. Offspring development was positively affected since larvae hatched earlier from eggs and subsequently pupated faster on TSWV-infected plants. These results show a mutualistic relationship between $F$. occidentalis and TSWV.
\end{abstract} preference tests. In addition, more offspring were produced on the virus-

The western flower thrips, Frankliniella occidentalis (Pergande) (Thysanoptera: Thripidae), is a serious pest of vegetable and ornamental crops worldwide. Direct injury caused by thrips includes growth reduction and cosmetic damage to fruits and flowers. F. occidentalis is the main vector for some tospoviruses (family Bunyaviridae) (14), of which Tomato spotted wilt virus (TSWV) is the most detrimental $(5,6)$. Young larvae (L1 and early L2 stage) usually acquire the virus from infected plants on which they emerge (12). The virus is propagatively transmitted, i.e., replicates in the vector $(11,17)$, and viruliferous adults are able to transmit the virus indefinitely (17). Because larvae develop on the plants on which they hatched, acquisition of TSWV is dependent on female thrips ovipositing on virus-infected plants.

Studies with Lactuca sativa L., Arctium lappa L., and Datura stramonium L. demonstrated that $F$. occidentalis produced more offspring on TSWV-infected plants than they did on noninfected plants (1). It was not established whether this increased reproduction was because of higher numbers of females being attracted to virus-infected plants, or enhanced fecundity due to elevated oviposition, hatching rates, or both, or because of reduced mortality of progeny.

TSWV infection of thrips has no apparent deleterious effects, since developmental time, reproduction rate, and survival were similar for viruliferous thrips and nonviruliferous thrips when fed for short periods on tospovirus-infected Nicotiana rustica L. plants $(15,16)$. However, exposing thrips to infected plants for long periods may affect thrips longevity. TSWV infection of chrysanthemum plants had no effect on the mortality of $F$. occidentalis. (10), but thrips development on Impatiens necrotic spot virus-infected Lobelia erinus L. plants was significantly slower than on noninfected plants (2).

In the current study, preference of $F$. occidentalis for TSWVinfected versus noninfected plants was analyzed, as well as possible differences in oviposition rates on these hosts. In addition,

Corresponding author: D. Peters; E-mail address: dick.peters@wur.nl

Publication no. P-2004-0510-03R

(C) 2004 The American Phytopathological Society
Additional keywords: preference, reproduction, thrips.

the effect of TSWV infection of the host on female thrips behavior and oviposition and subsequent development of progeny were assessed.

\section{MATERIALS AND METHODS}

Thrips population, plants, virus isolates, and inoculations. The population of $F$. occidentalis 'IS2' used in this study originated from an infestation on mango in Israel (13). This virus-free population was reared on chrysanthemum plants at $23 \pm 2.0^{\circ} \mathrm{C}$ under a 16-h light and 8-h dark cycle in the greenhouse.

Three Capsicum annuum L. accessions, "Pikante Reuzen", highly susceptible to $F$. occidentalis (TS, "thrips susceptible"); "CPRO-1", resistant to F. occidentalis (TR, "thrips resistant") (8); and Mazurka RZ were used. The experimental host Datura stramonium L. also was used in comparative studies.

The TSWV isolate BR01 (3) was maintained by thrips-mediated passages on $D$. stramonium plants. To obtain TSWV-infected plants, leaf tissue from systemically infected $D$. stramonium plants was ground in $0.05 \mathrm{M}$ of sodium phosphate buffer, $\mathrm{pH}$ 7.0. Inocula were rubbed on Carborundum-dusted leaves of 2- to 3 -week-old seedlings. Control plants were inoculated with buffer only. Plants with obvious symptoms were used in the experiments approximately 2 to 3 weeks postinoculation.

Preference of thrips for TSWV-infected versus noninfected pepper plants. The effect of TSWV infection in plants of TR and TS accessions on the preference of thrips was determined with two experimental designs. In the first design, thrips could disperse toward 4- to 5-week-old TSWV-infected or noninfected plants after the release of 20 adults at a spot between two plants placed at a distance of $30 \mathrm{~cm}$ from each plant in transparent, plastic cages $(45 \times 30 \times 40 \mathrm{~cm})$. In the second design, dispersal of thrips from an infected or noninfected plant to a neighboring plant was studied using the release of 20 adults on one of the two plants. The thrips could move between an infected and noninfected plant (choice test) or between two infected or two noninfected plants (nonchoice tests). Dispersal of thrips was measured by scoring the number of thrips present on each plant every hour for the first $8 \mathrm{~h}$, and then at 24, 48, 72, 96, and $168 \mathrm{~h}$ after the release. All leaves were visually inspected by careful turning so 
the adults did not escape. Each experiment contained six sets of plants and was replicated twice. Experiments were performed at $23 \pm 2.0^{\circ} \mathrm{C}$ under a 16 -h light and 8 -h dark cycle in a climate chamber.

The rates of thrips dispersal from infected and noninfected plants were compared by analysis of variance using generalized linear models and Genstat (9) with the log-transformed numbers of thrips present on the plants as binomial distributed variables.

Preferential oviposition on TSWV-infected plants. Preference for and reproduction of $F$. occidentalis females on TSWV infected or noninfected plants were compared. Twenty virus-free females were released in plastic cages $(45 \times 30 \times 40 \mathrm{~cm})$ with a transparent lid. Four virus-infected or noninfected seedlings of TS, TR, Mazurka RZ, or D. stramonium were placed in the cages for nonchoice tests, whereas two infected and two noninfected plants of each accession were arranged side-by-side for choice tests. Each nonchoice and choice test contained six sets of plants and was repeated twice. Cages were placed in the greenhouse at $23 \pm 2.0^{\circ} \mathrm{C}$ under a 16 -h light and 8 -h dark cycle. Females were allowed to oviposite on the plants for 3 days, after which the females were counted and subsequently removed from the plants with an aspirator. Offspring were collected and counted every 24 $\mathrm{h}$ for 7 days after removal of the adults. Leaves of each plant were stained with $1.5 \%$ methyl red to detect unhatched eggs, which were counted under a binocular microscope. The number of females and offspring per female recovered from virus-infected and noninfected plants was analyzed and compared for each accession by Kruskal-Wallis one-way analysis of variance using Genstat (9).

Behavior of female thrips on TSWV-infected and noninfected plants. The behavior of $F$. occidentalis females on TSWV-infected and noninfected plants was visually assessed by releasing 20 thrips on one of the top leaves of either plant in a cage. The duration of periods that a randomly selected thrips was
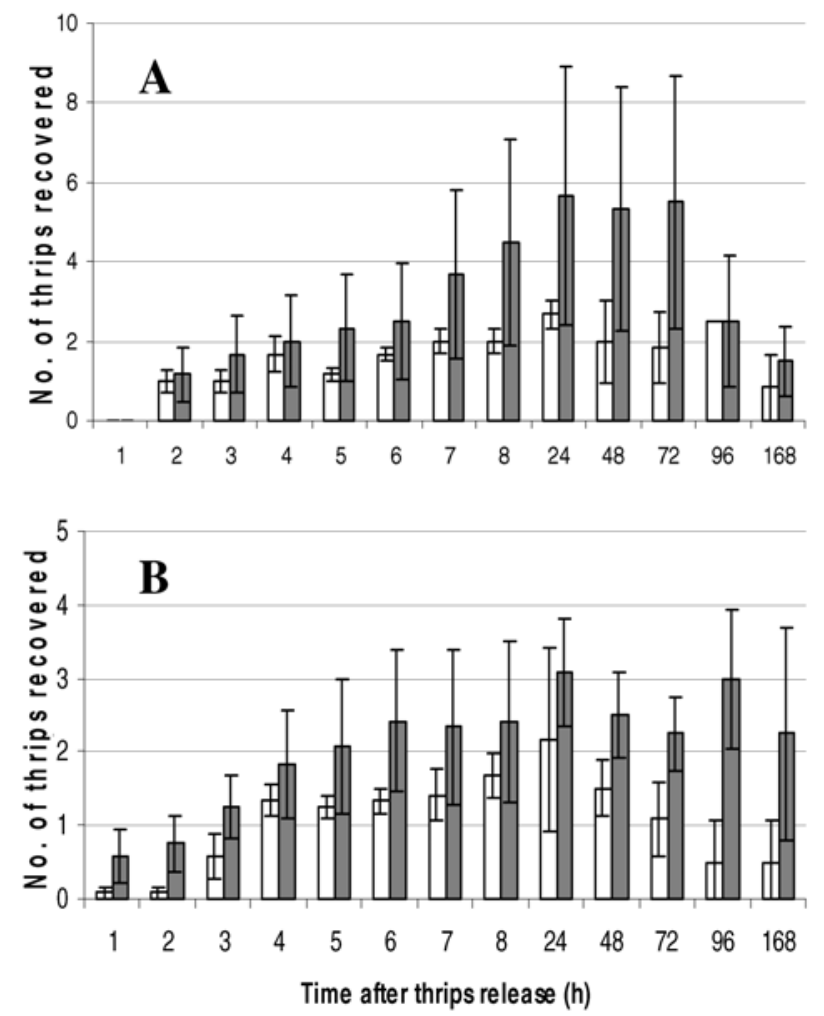

Fig. 1. Mean number of thrips recovered in three replicates on Tomato spotted wilt virus-infected (shaded bars) or noninfected (white bars) thrips susceptible (TS) pepper plants in A, choice and $\mathbf{B}$, nonchoice tests. Twenty adults were released at the beginning of the experiment at a spot between the two plants. Error bars indicate the standard error of the mean. "walking" (moving) or "not-walking" (resting or not moving) on the leaves and the number of these periods were visually monitored and scored for $10 \mathrm{~min}$ at $5 \mathrm{~min}$ and 1, 2, 3, 4, 5, 6, 7, 8, 24, 48,72 , and $96 \mathrm{~h}$ after thrips release. For each time point, the behavior (walking and not-walking) of six individual thrips on infected and noninfected host plants was scored. Total fraction of time and number of periods that thrips were "resting" on plants of both accessions were analyzed as binomial and Poisson distributed variables, respectively, using regression analysis.

Thrips development on TSWV-infected plants. To study whether TSWV infection of plants affects thrips development, three females were confined to leaf disks $(2.5 \mathrm{~cm}$ in diameter [i.d.]) of TSWV-infected or noninfected plants. Disks were placed on $1.5 \%$ agar in a petri dish $(3.5 \mathrm{~cm}$ i.d.) covered with cling film and incubated at $24^{\circ} \mathrm{C}$. Adults had access to the leaf disks for an oviposition period of $12 \mathrm{~h}$, after which the adults were removed. Larvae hatching from eggs were individually transferred to new leaf disks of infected or noninfected plants depending on their original host. Thrips development was monitored every $12 \mathrm{~h}$ until adult emergence. The duration of each developmental stage of thrips feeding on TSWV-infected disks and on noninfected disks was compared. This experiment was performed in duplicate with pepper (TS and Mazurka RZ) and D. stramonium plants with development of 20 to 30 individual thrips scored for each treatment. Simple linear regression models analyzed possible effects of thrips resistance on thrips developmental rate. Computations to indicate statistical significance were based on $95 \%$ confidence intervals.

\section{RESULTS}

Preference of thrips for TSWV-infected versus noninfected pepper plants. Consistently higher numbers of thrips were found on infected plants than were found on noninfected plants when
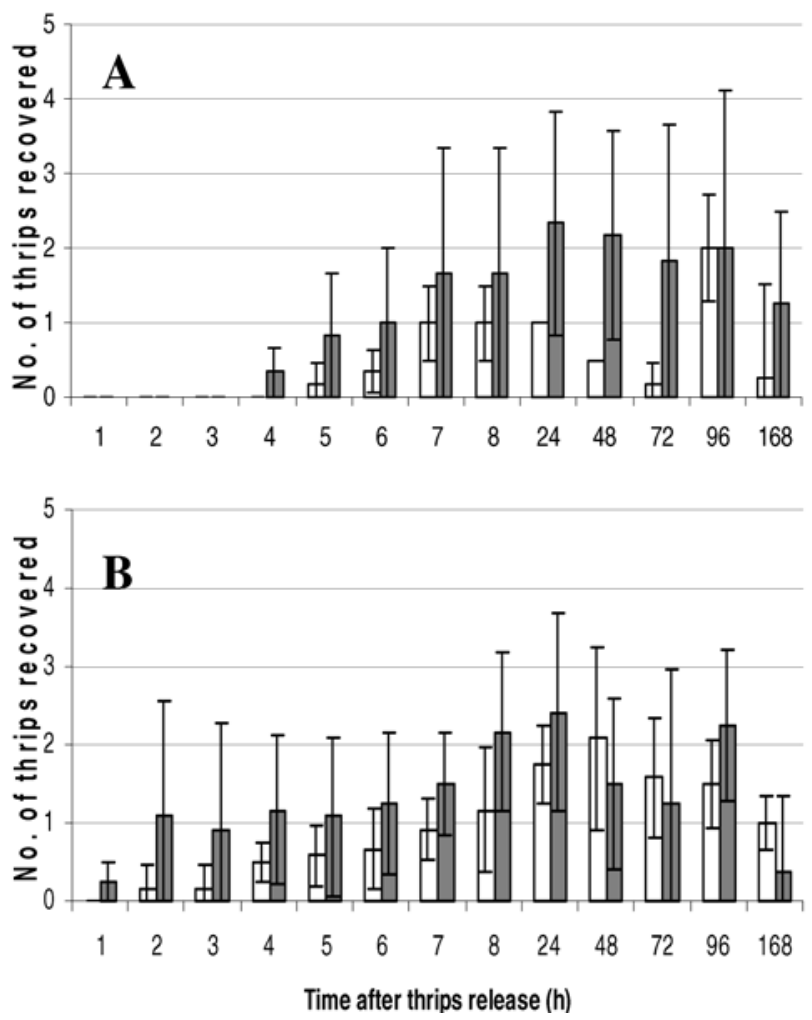

Fig. 2. Mean number of thrips recovered in three replicates on Tomato spotted wilt virus-infected (shaded bars) or noninfected (white bars) thrips resistant (TR) pepper plants in $\mathbf{A}$, choice and $\mathbf{B}$, nonchoice tests. Twenty adults were released at the beginning of the experiment at a spot between the two plants. Error bars indicate the standard error of the mean. 
thrips were released at a spot between an infected and a noninfected plant. This was found for both the TS and TR accessions (Figs. 1A and 2A). While the number of thrips did not significantly differ $(P>0.05)$ at each time interval, the cumulative numbers of thrips recovered on TSWV-infected TS $(38.3 \pm 3.9)$ and TR $(15.1 \pm 5.3)$ plants were significantly $(P<0.05)$ higher than on noninfected TS $(20.3 \pm 1.1)$ and TR $(6.4 \pm 1.8)$ plants. A similar trend was found in preference tests in which thrips were allowed to choose between two infected or two noninfected TS (Fig. 1B) or TR (Fig. 2B) plants. The cumulative number of thrips recovered was again significantly $(P<0.05)$ higher on infected TS $(26.8 \pm 6.9)$ and TR $(17.2 \pm 4.7)$ plants than it was on noninfected TS $(13.5 \pm 3.2)$ and TR $(12.1 \pm 0.9)$ plants.

In a slightly different experimental design, adult females were released on one of two plants instead of being released in between the plants. The thrips were again allowed to choose between two infected or two noninfected plants in a cage (nonchoice tests) of the TS (Fig. 3) or TR (Fig. 4) accession, or between one infected and one noninfected TS (Fig. 5) or TR (Fig. 6) plant (choice tests). Of the 20 females released in each treatment, 10 to 15 were recovered after $1 \mathrm{~h}$ on the plant the thrips were released (Figs. 3 to 6). Beyond this first hour, thrips dispersed slowly from the source plant and colonized the companion plant at a low rate. Most thrips could not be recovered on either plant and probably went astray in the cage. However, this dispersal was lower from infected TS (Figs. 3A and 5A) or TR (Figs. 4A and 6A) plants than from noninfected TS (Figs. 3B and 5B) or TR (Figs. 4B and $6 \mathrm{~B})$ plants, independent of whether the neighboring plant was infected or not. Log-transformation of thrips numbers on the plants at each time point confirmed this conclusion (Table 1).
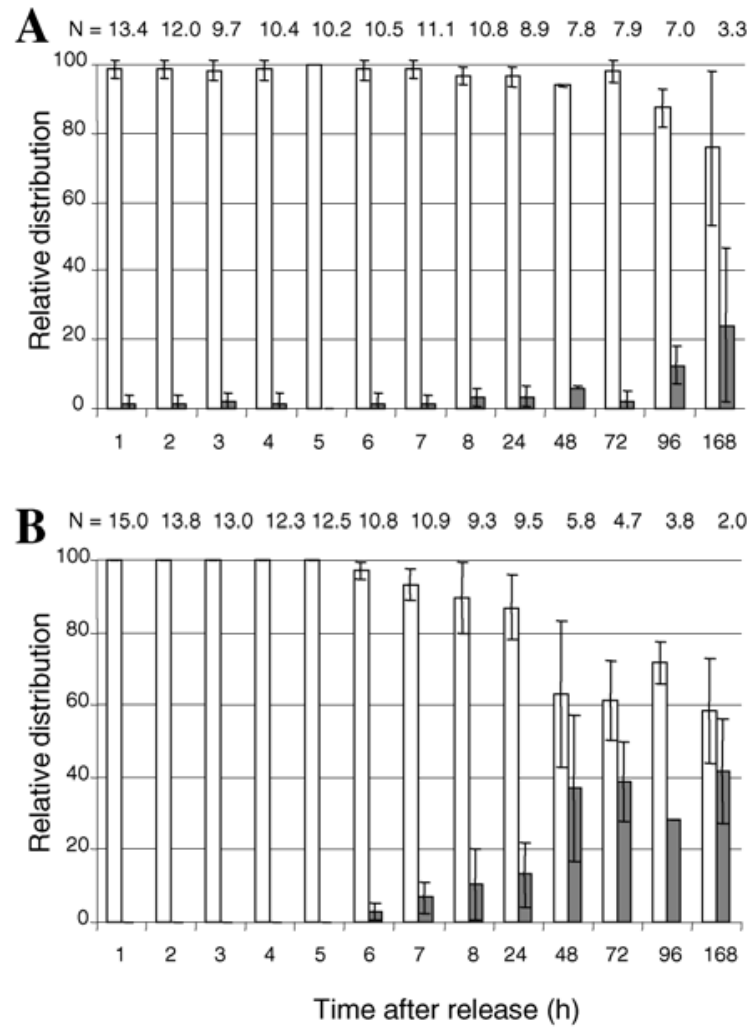

Fig. 3. Dispersal of Frankliniella occidentalis among A, two Tomato spotted wilt virus-infected or $\mathbf{B}$, two noninfected thrips susceptible (TS) pepper plants placed in a cage (nonchoice tests) after release of 20 adults on one plant per cage. Thrips were counted every hour during the first $8 \mathrm{~h}$ after release and every $24 \mathrm{~h}$ thereafter. The mean number of thrips recovered on both plants in two replicates is given above the bar graphs for each time point. White bars represent thrips numbers on plants on which they were released, and shaded bars represent thrips numbers on plants to which they migrated. Error bars indicate the standard error of the mean.
Slopes of the regression lines confirmed that thrips left noninfected TS plants (slope -0.51) and TR plants (slope -0.70) at higher rates than they left infected TS plants (slope -0.22$)$ and TR plants (slope -0.39$)(P<0.05)$. Thrips could not be detected on both the healthy TR plant and its healthy TR neighbor after $72 \mathrm{~h}$, while some thrips could be found on both infected TR plants (Fig. 4). These results showed that a large number of the thrips could not be recovered on the plants on which they were released. In an initial experiment, the first counts were made $8 \mathrm{~h}$ after the release of thrips instead of each hour during this time span. The number of thrips recovered after these $8 \mathrm{~h}$ did not differ from that in experiments in which the thrips were counted every hour (data not shown). These results indicate that the low recoveries were attributed to dispersal of thrips throughout the cage and not to the escape of thrips when cages were opened for counting.

Preferential oviposition on TSWV-infected plants. Significantly more females were recovered and more offspring were produced on TSWV-infected plants than on noninfected plants in choice and nonchoice tests for all four hosts (three pepper accessions and D. stramonium) tested (Table 2). The offspring produced on the TSWV-infected plants was positively correlated with the number of females recovered on these plants. Staining leaves with methyl red indicated that the number of unhatched eggs in the TSWV-infected leaves from TR, TS, and D. stramonium did not differ from that in noninfected leaves (data not shown).

Behavior of female thrips on TSWV-infected and noninfected plants. The period that thrips did not walk was longer than the period in which they walked. The average total period that an individually monitored thrips did not walk ranged between
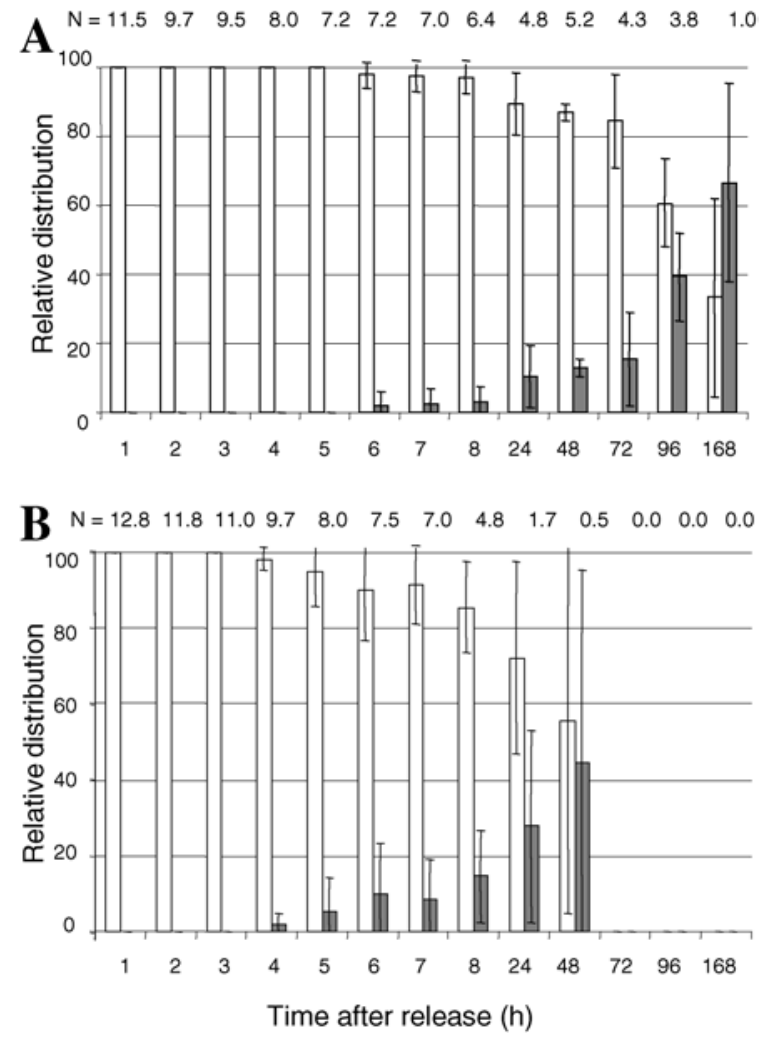

Fig. 4. Dispersal of Frankliniella occidentalis among A, two Tomato spotted wilt virus-infected or $\mathbf{B}$, two noninfected thrips resistant (TR) pepper plants placed in a cage (nonchoice tests) after release of 20 adults on one plant per cage. Thrips were counted every hour during the first $8 \mathrm{~h}$ after release and every $24 \mathrm{~h}$ thereafter. The mean number of thrips recovered on both plants in two replicates is given above the bar graphs for each time point. White bars represent thrips numbers on plants on which they were released, and shaded bars represent thrips numbers on plants to which they migrated. Error bars indicate the standard error of the mean. 
7.7 and $9.8 \mathrm{~min}$ in the $10 \mathrm{~min}$ that the thrips were observed. The number of "not-walking" periods varied between 1.8 and 6.8 . These behavioral parameters of thrips did not differ for infected and noninfected TS and infected and noninfected TR plants for all time points scored (data not shown; $P>0.10$ ). In these observations, no distinction could be made between thrips that were just resting when they did not walk or that they were probing and/or feeding. No eggs were deposited during the $52 \mathrm{~h}$ that these observations were made.

Thrips development on TSWV-infected plants. Larvae hatched significantly $(P<0.05)$ earlier from eggs on TSWV-infected leaf disks than they did from eggs on noninfected disks (Table 3). Larvae developed significantly $(P<0.05)$ faster on TSWV-infected pepper (Mazurka RZ) and D. stramonium leaf disks (4.4 and 4.6 days, respectively) than they did on noninfected disks (5.9 and 6.1 days, respectively). The development of both pupal stages was not affected by TSWV infection. Overall, the complete development from egg to adult required 1 to 2 days less on TSWV-infected leaf disks (Table 3). No difference in mortality was observed among thrips reared on disks of noninfected and infected plants (data not shown).

\section{DISCUSSION}

The current study demonstrates that TSWV infection improves host suitability for its vector $F$. occidentalis. TSWV-infected plants gained attractiveness for female thrips and also were preferred for feeding and, most importantly for TSWV epidemics, for oviposition. These parameters are of significant importance with respect to abundance of viruliferous vectors in the field. The
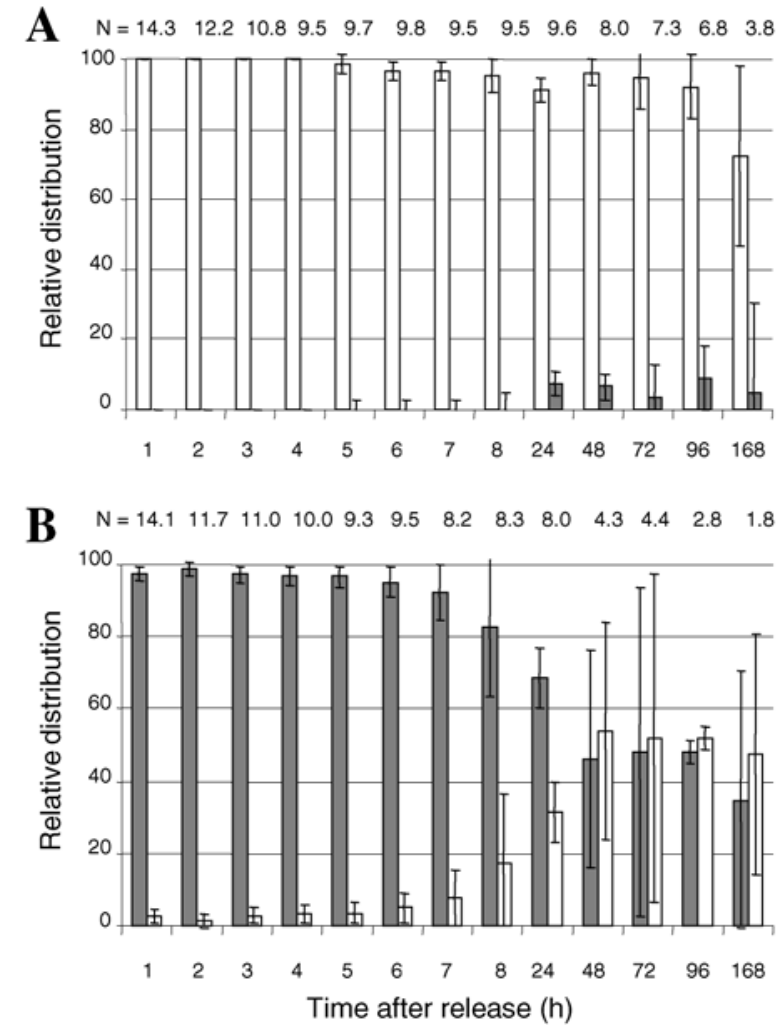

Fig. 5. Dispersal of Frankliniella occidentalis between a Tomato spotted wilt virus-infected (white bars) and a noninfected (shaded bars) thrips susceptible (TS) pepper plant placed in a cage (choice tests) after release of 20 adults on one plant per cage. Thrips were counted every hour during the first $8 \mathrm{~h}$ after release and every $24 \mathrm{~h}$ thereafter. The mean number of thrips recovered on both plants in two replicates is given above the bar graphs for each time point. White bars represent thrips numbers on plants on which they were released, and shaded bars represent thrips numbers on plants to which they migrated. Error bars indicate the standard error of the mean. preference of thrips for oviposition and faster development of progeny on TSWV-infected plants would result in more viruliferous thrips than if the infection status of host plants had no effect.

Thrips preferred feeding on TSWV-infected pepper plants. This effect was shown in experiments in which females were released between or on TSWV-infected or noninfected plants (Figs. 1 to 6). Most strikingly, a large number of thrips were not recovered on the plants after release. In those experiments in which thrips were released between the plants, the number of thrips recovered increased slightly in the first days after introduction into the cage (Figs. 1 and 2). Although small, this increase indicates that the dispersed thrips did not die, but went astray in the cage. The higher number of thrips recovered on the TSWV-infected plants compared to noninfected plants shows that TSWV-infected plants were attractive to thrips. Thrips might be attracted by the yellow color of virus-infected host plants as reported for TSWV-infected lettuce plants (18). Alternatively, TSWV-infected plants may release specific volatiles that attract thrips, as was found for Potato leaf roll virus (PLRV)-infected potato plants attracting the aphid vector Myzus persicae Sulz. (4). Another explanation for higher thrips numbers on infected plants is that thrips disperse at a lower rate from infected plants compared with noninfected plants. This explanation is supported by the larger number of thrips on infected plants compared with noninfected plants in experiments in which thrips were released on one of two caged plants (Figs. 3 to 6).

Considerably more eggs were produced on infected plants compared with noninfected plants (Table 1). The number of larvae that hatched on either plant was closely correlated with the number of females recovered. Increased ovipositions on infected
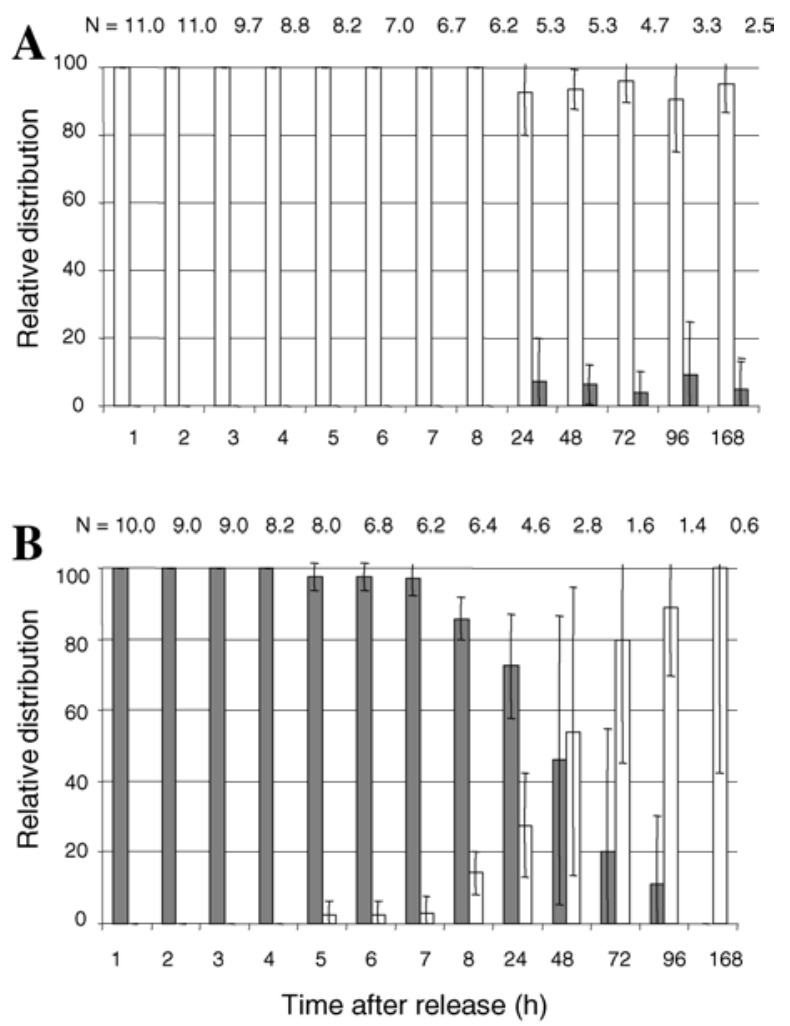

Fig. 6. Dispersal of Frankliniella occidentalis among a Tomato spotted wilt virus-infected (white bars) and a noninfected (shaded bars) thrips resistant (TR) pepper plant placed in a transparent cage (choice tests) after release of 20 adults on one plant per cage. Thrips were counted every hour during the first $8 \mathrm{~h}$ after release and every $24 \mathrm{~h}$ thereafter. The mean number of thrips recovered on both plants in two replicates is given above the bar graphs for each time point. Open bars represent thrips numbers on plants upon which they were released; shaded bars represent thrips numbers on plants to which they migrated. Error bars indicate the standard error of the mean. 
TABLE 1. Regression functions after log-transformation of the number of thrips $(Y)$ recovered on Tomato spotted wilt virus-infected and noninfected thrips susceptible (TS) or thrips resistant (TR) pepper plants. Twenty thrips were released on a source plant that was placed next to another plant (neighboring plant) in a thrips-proof cage. " $R$ " " indicates the correlation coefficient of the regression function. Corresponding figure indicates the figure in which the nontransformed thrips numbers is given.

\begin{tabular}{|c|c|c|c|c|c|}
\hline Pepper phenotype & Source plant & Neighboring plant & Regression function & $R^{2}$ & Corresponding figure \\
\hline \multirow[t]{2}{*}{ TS } & Infected & Infected & $Y=-0.22 \mathrm{x}+1.17 \mathrm{a}^{\mathrm{z}}$ & 0.68 & $3 \mathrm{~A}$ \\
\hline & Infected & Noninfected & $Y=-0.21 \mathrm{x}+1.15 \mathrm{a}$ & 0.76 & $5 \mathrm{~A}$ \\
\hline \multirow[t]{4}{*}{ TR } & Infected & Infected & $Y=-0.48 \mathrm{x}+1.20 \mathrm{a}$ & 0.71 & $4 \mathrm{~A}$ \\
\hline & Noninfected & Infected & $Y=-0.72 \mathrm{x}+1.27 \mathrm{~b}$ & 0.81 & $6 \mathrm{~B}$ \\
\hline & Infected & Noninfected & $Y=-0.29 \mathrm{x}+1.10 \mathrm{a}$ & 0.92 & $6 \mathrm{~A}$ \\
\hline & Noninfected & Noninfected & $Y=-0.68 \mathrm{x}+1.30 \mathrm{~b}$ & 0.88 & $4 \mathrm{~B}$ \\
\hline
\end{tabular}

${ }^{\mathrm{z}}$ Different letters in two subsequent rows indicate significant differences $(P<0.05)$ between dispersal rate of thrips from an infected source plant or a noninfected source plant to a neighboring plant with the same infection status.

TABLE 2. Mean numbers of Frankliniella occidentalis females and offspring per female recovered on Tomato spotted wilt virus-infected and noninfected thrips susceptible (TS) or thrips resistant (TR) pepper cv. Mazurka RZ and Datura stramonium plants. Twenty adults were released in cages with two infected and noninfected plants (choice tests) or in cages with four virus-infected or noninfected plants (nonchoice test). Means are presented with the standard error of the mean

\begin{tabular}{|c|c|c|c|c|c|c|c|c|}
\hline \multirow[b]{3}{*}{ Test plant } & \multicolumn{4}{|c|}{ Average number of females recovered } & \multicolumn{4}{|c|}{ Average number of offspring per female released } \\
\hline & \multicolumn{2}{|c|}{ Choice test } & \multicolumn{2}{|c|}{ Nonchoice test } & \multicolumn{2}{|c|}{ Choice test } & \multicolumn{2}{|c|}{ Nonchoice test } \\
\hline & Infected & Noninfected & Infected & Noninfected & Infected & Noninfected & Infected & Noninfected \\
\hline TS & $5.2 \pm 0.9 \mathrm{a}$ & $0.5 \pm 0.1 \mathrm{~b}$ & $6.8 \pm 0.7 \mathrm{a}$ & $3.1 \pm 0.9 \mathrm{~b}$ & $2.3 \pm 0.5 \mathrm{a}$ & $0.1 \pm 0.1 \mathrm{~b}$ & $7.1 \pm 0.7 \mathrm{a}$ & $0.7 \pm 0.2 b$ \\
\hline Mazurka RZ & $4.5 \pm 0.8 \mathrm{a}$ & $0.3 \pm 0.2 \mathrm{~b}$ & $7.2 \pm 0.3 \mathrm{a}$ & $2.3 \pm 1.0 \mathrm{~b}$ & $4.9 \pm 1.0 \mathrm{a}$ & $0.2 \pm 0.1 \mathrm{~b}$ & $6.1 \pm 0.7 \mathrm{a}$ & $1.0 \pm 0.1 \mathrm{~b}$ \\
\hline D. stramonium & $6.5 \pm 0.5 \mathrm{a}$ & $4.3 \pm 0.4 b$ & $7.0 \pm 0.6 \mathrm{a}$ & $3.5 \pm 0.9 \mathrm{~b}$ & $2.6 \pm 0.3 \mathrm{a}$ & $0.8 \pm 0.2 \mathrm{~b}$ & $3.6 \pm 0.5 \mathrm{a}$ & $1.1 \pm 0.2 b$ \\
\hline
\end{tabular}

${ }^{\mathrm{z}}$ Different letters in a row for females or offspring indicate significant differences between values $(P<0.05)$ for choice or nonchoice tests.

TABLE 3. Mean duration (days) of the developmental stages of Frankliniella occidentalis reared on leaf disks from Tomato spotted wilt virus-infected and noninfected pepper (thrips susceptible [TS] or Mazurka RZ) and Datura stramonium plants at $24^{\circ} \mathrm{C}$. Means are presented with the standard error of the mean

\begin{tabular}{llccccr}
\hline & & \multicolumn{4}{c}{ Length of a developmental stage (days) } \\
\cline { 3 - 5 } Plant & Health status & Egg & Larval & Prepupal & Pupal & No. of days from egg to adult \\
\hline Capsicum annuum (TS) & Infected & $3.0 \pm 0.0 \mathrm{a}^{\mathrm{z}}$ & $4.7 \pm 0.1 \mathrm{a}$ & $1.0 \pm 0.0 \mathrm{a}$ & $2.2 \pm 0.1 \mathrm{a}$ & $10.9 \pm 0.2 \mathrm{a}$ \\
& Noninfected & $3.4 \pm 0.1 \mathrm{~b}$ & $5.2 \pm 0.1 \mathrm{a}$ & $1.0 \pm 0.0 \mathrm{a}$ & $2.5 \pm 0.2 \mathrm{a}$ & $12.1 \pm 0.1 \mathrm{~b}$ \\
C. annuum Mazurka RZ & Infected & $3.3 \pm 0.1 \mathrm{a}$ & $4.4 \pm 0.2 \mathrm{a}$ & $0.9 \pm 0.1 \mathrm{a}$ & $2.0 \pm 0.2 \mathrm{a}$ & $10.6 \pm 0.1 \mathrm{a}$ \\
& Noninfected & $3.6 \pm 0.1 \mathrm{~b}$ & $5.9 \pm 0.1 \mathrm{~b}$ & $1.2 \pm 0.1 \mathrm{a}$ & $2.2 \pm 0.1 \mathrm{a}$ & $12.9 \pm 0.1 \mathrm{~b}$ \\
D. stramonium & Infected & $3.1 \pm 0.0 \mathrm{a}$ & $4.6 \pm 0.1 \mathrm{a}$ & $1.1 \pm 0.1 \mathrm{a}$ & $2.3 \pm 0.1 \mathrm{a}$ & $1.1 \pm 0.2 \mathrm{a}$ \\
& Noninfected & $3.4 \pm 0.0 \mathrm{~b}$ & $6.1 \pm 0.2 \mathrm{~b}$ & $1.1 \pm 0.0 \mathrm{a}$ & $2.1 \pm 0.1 \mathrm{a}$ & $12.7 \pm 0.2 \mathrm{~b}$ \\
\hline
\end{tabular}

${ }^{\mathrm{z}}$ Different letters in a column for each plant species indicate significant differences between development of thrips on virus infected and noninfected leaf disks $(P<0.05)$.

plants likely result from a preference for these plants as a food source rather than from a higher oviposition rate per individual, different behavior, or lower mortality rate of eggs on infected plants. A preference of thrips for feeding and oviposition on TSWV-infected plants is supported by findings of Bautista et al. (1), although the underlying mechanism remained unknown in that study. Our results show that differences in thrips behavior and mortality of eggs are not involved, since these parameters were similar on TSWV-infected and noninfected plants regardless of which pepper accession was used.

In studies on the spread of TSWV between TR and TS plants, fewer TR plants became infected compared with TS plants when viruliferous thrips were introduced in cage and greenhouse experiments (7). These results were explained by a lower preference of thrips for the noninfected TR plants. Subsequently, the virus spread at a lower rate from the infected TR plants than it did from the TS plants, showing that infected TR plants (although becoming more attractive for thrips) remained a less suitable virus source for virus spread than infected TS plants. From these observations, we conclude that effect of the resistance in the TR accession is maintained, notwithstanding the gain in attractiveness of infected TR plants for thrips.

Our findings show a mutualistic relationship between $F$. occidentalis and TSWV. The attraction of thrips to TSWV-infected plants results in a larger population of viruliferous thrips, thereby, increasing the probability of TSWV transmission. Thrips also benefit, since TSWV-infected plants are more suitable hosts for thrips feeding, reproduction, and development.

\section{ACKNOWLEDGMENTS}

This research was financially supported by the Technology Foundation (STW) of the Netherlands Organization for Scientific Research (NWO) (project number WBI.4827).

\section{LITERATURE CITED}

1. Bautista, R. C., Mau, R. F. L., Cho, J. J., and Custer, D. M. 1995. Potential of tomato spotted wilt tospovirus plant hosts in Hawaii as virus reservoirs for transmission by Frankliniella occidentalis (Thysanoptera: Thripidae). Phytopathology 85:953-958.

2. DeAngelis, J. D., Sether, D. M., and Rossignol, P. A. 1993. Survival, development, and reproduction in western flower thrips (Thysanopthera: Tripidae) exposed to impatiens necrotic spot virus. Environ. Entomol. 22:1308-1312.

3. de Ávila, A. C., Huguenot, C., Resende, R. de O., Kitajima, E. W., Goldbach, R. W., and Peters, D. 1990. Serological differentiation of 20 isolates of tomato spotted wilt virus. J. Gen. Virol. 71:2801-2807.

4. Eigenbrode, S. D., Ding, H., Shiel, P., and Berger, P. H. 2002. Volatiles from potato plants infected with potato leafroll virus attract and arrest the 
virus vector, Myzus persicae (Homoptera: Aphididae). Proc. R. Soc. London 269:455-460.

5. German, T. L., Ullman, D. E., and Moyer, J. W. 1992. Tospoviruses: Diagnosis, molecular biology, phylogeny and vector relationships. Annu. Rev. Phytopathol. 30:315-348.

6. Goldbach, R., and Peters, D. 1994. Possible causes of the emergence of tospovirus diseases. Seminars of Virology 5:113-120.

7. Maris, P. C., Joosten, N. N., Goldbach, R. W., and Peters, D. 2003. Restricted spread of Tomato spotted wilt virus in thrips-resistant pepper. Phytopathology 93:1223-1227.

8. Maris, P. C., Joosten, N. N., Peters, D., and Goldbach, R. W. 2003. Thrips resistance in pepper and its consequences for the acquisition and inoculation of Tomato spotted wilt virus (TSWV) by the Western flower thrips. Phytopathology 93:96-101.

9. Payne, R. W., Lane, P. W., Digby, P. G. N., Harding, S. A., Leech, P. K., Morgan, G. W., Todd, A. D., Thompson, R., Tunnicliffe Wilson, G., Welham, S. J., and White, R. P. 1993. Genstat 5 Release 3 Reference Manual. Clarendon Press, Oxford, U.K.

10. Robb, K. L. 1989. Analysis of Frankliniella occidentalis (Pergande) as a pest of floricultural crops in California greenhouses. Ph.D. thesis. University of California, Riverside.

11. Ullman, D. E., German, T. L., Sherwood, J. L., Westcot, D. M., and Cantone, F. A. 1993. Tospovirus replication in insect vector cells: Immuno-cytochemical evidence that the nonstructural protein encoded by the S RNA of tomato spotted wilt tospovirus is present in thrips vector cells. Phytopathology 83:456-463.
12. van de Wetering, F., Goldbach, R., and Peters, D. 1996. Tomato spotted wilt tospovirus ingestion by first instar larvae of Frankliniella occidentalis is a prerequisite for transmission. Phytopathology 86:900905.

13. van de Wetering, F., van der Hoek, M., Goldbach, R., Mollema, C., and Peters, D. 1999. Variation in tospovirus transmission between populations of Frankliniella occidentalis (Thysanoptera; Thripidae). Bull. Entomol. Res. 89:579-588.

14. Wijkamp, I., Almarza, N., Goldbach, R., and Peters, D. 1995. Distinct levels of specificity in thrips transmission of tospoviruses. Phytopathology 85:1069-1074.

15. Wijkamp, I., Goldbach, R., and Peters, D. 1995. Effect of tomato spotted wilt virus infection on survival, development and reproduction on the vector Frankliniella occidentalis. Proc. Exp. Appl. Entomol. J. H. Sommeijer and P. J. Francke, eds. NEV, Amsterdam 6:207-214.

16. Wijkamp, I., Goldbach, R., and Peters, D. 1996. Propagation of tomato spotted wilt virus in Frankliniella occidentalis does neither result in pathological effects nor in transovarial passage of the virus. Entomol. Exp. Appl. 81:285-292.

17. Wijkamp, I., van Lent, J., Goldbach, R., and, Peters, D. 1993. Multiplication of tomato spotted wilt virus in its vector, Frankliniella occidentalis. J. Gen. Virol. 74:341-349.

18. Yudin, L. S., Mitchell, W. C., and Cho, J. J. 1987. Color preference of thrips (Thysanoptera: Thripidae) with reference to aphids (Homoptera: Aphididae) and leafminers in Hawaiian lettuce farms. J. Econ. Entomol. 80:51-55. 